\title{
Is drip irrigation sustainable in the salt affected soil of the San Joaquin Valley of California?
}

\author{
D. May \& B. Hanson \\ Department of Land, Air and Water Resources, \\ University of California, Davis, USA
}

\begin{abstract}
Many areas along the west side of the San Joaquin Valley of California are affected by saline soil due to shallow, saline ground water conditions. Artificial subsurface drainage is not an option for addressing the salinity problem because of the lack of drainage water disposal facilities. Thus, the salinity/drainage problem of the valley must be addressed through improved irrigation practices such as converting to drip irrigation. The effect of drip irrigation on processing tomato yield and quality, soil salinity, soil water content, and water table depth was evaluated in four commercial fields located in the San Joaquin Valley of California, USA. Results showed drip irrigation of processing tomatoes to be highly profitable under these conditions compared to sprinkle irrigation. No trend in tomato yield was found with soil salinity levels. While a water balance showed little or no field-wide leaching, soil salinity data clearly showed localized leaching around the drip lines.

Keywords: drip irrigation, processing tomatoes, soil salinity, water table, subsurface drip irrigation, leaching, saline, ground water, tomato, salinity.
\end{abstract}

\section{Introduction}

About 1 million ha of irrigated land are affected by saline, shallow ground water conditions along the west side of the San Joaquin Valley. Upward flow of the shallow groundwater has resulted in excessive levels of root-zone soil salinity. The traditional approach to dealing with shallow ground water problems is to install subsurface drainage systems for water table control and improved leaching, but the proper operation of these drainage systems requires disposal of the subsurface drainage water. No economically, technically, and 
environmentally feasible drain water disposal method exists for the San Joaquin Valley, and thus, the drainage problem must be addressed through options such as better management of irrigation water to reduce drainage below the root zone, increasing crop water use of the shallow groundwater without any yield reductions, and drainage water reuse for irrigation [1]. One option for improving irrigation water management is to convert from furrow or sprinkler irrigation to drip irrigation.

Drip irrigation can apply water both precisely and uniformly compared with furrow and sprinkler irrigation resulting in the potential to reduce subsurface drainage, control soil salinity, and increase yield. The main disadvantage of drip irrigation is its cost, which based on grower experience can be as much as $\$ 2,470 /$ ha. For drip irrigation to be at least as profitable as the other irrigation methods, more revenue from higher yields and reduced irrigation and cultural costs must occur. Yet, several large-scale comparisons of furrow and drip irrigation of cotton revealed uncertainty in the economic benefits of drip irrigation [2,3]. Thus, growers converting to drip irrigation face uncertainty about the economic risks involved.

Subsurface drip irrigation of processing tomatoes was evaluated to determine its effect on crop yield and quality, soil salinity, water table depth, and profitability in salt-affected, fine-textured soil underlain by saline, shallow groundwater. Because tomatoes are a high cash value crop, a better potential for increased profitability with drip irrigation exists compared to cotton. However, tomatoes are much more sensitive to soil salinity, which could result in reduced crop yields in salt-affected soil.

\section{Methods and materials}

Experiments in three commercial fields involved comparing subsurface drip irrigation of processing tomatoes with sprinkle irrigation under saline, shallow ground water conditions [4]. Drip irrigation systems ranged from 16 ha to 32 ha in size. Field length was $400 \mathrm{~m}$. Drip lines were buried 0.2 to $0.305 \mathrm{~m}$ deep, depending on the field. Drip irrigations occurred every two to three days. At one field, water table depths were about $2 \mathrm{~m}$, while at the other two fields, water table depths generally ranged between $0.5 \mathrm{~m}$ and $1 \mathrm{~m}$. The electrical conductivity (EC) of the irrigation water was about 0.30 to $0.35 \mathrm{dS} \mathrm{m}^{-1}$ at two fields, and was 1.06 to $1.2 \mathrm{dS} \mathrm{m}^{-1}$ at the third field. The EC of the shallow ground water ranged from $4.7 \mathrm{dS} \mathrm{m}^{-1}$ to $16.4 \mathrm{dS} \mathrm{m}^{-1}$, depending on the particular field and time of year. Soil type was clay loam at the three sites. In addition, a small-plot randomized replicated experiment was superimposed on each drip system with irrigation treatments consisting of different amounts of irrigation water to determine the minimum amount of water that can be applied under saline, shallow ground water conditions without reducing crop yield.

At the fourth commercial field, a small-scale randomized replicated experiment was conducted under conditions of very shallow ground water, with water table depths between $0.45 \mathrm{~m}$ and $0.61 \mathrm{~m}$. Treatments consisted of different amounts of applied irrigation water. Drip irrigations occurred daily. The 
electrical conductivity of the irrigation water was $0.52 \mathrm{dS} \mathrm{m}^{-1}$. The electrical conductivity of the shallow ground water ranged from 8 to $11 \mathrm{dS} \mathrm{m}^{-1}$.

\section{Results and discussion}

Over a three-year period, the yields of the three large-scale subsurface drip systems were $12.1 \mathrm{Mg} \mathrm{ha}^{-1}$ to $22.6 \mathrm{Mg} \mathrm{ha}^{-1}$ higher than those of sprinkle irrigation [4]. The average yield of three drip-irrigated fields was $93.7 \mathrm{Mg} \mathrm{ha}^{-1}$ compared to $74.8 \mathrm{Mg} \mathrm{ha}^{-1}$ under sprinkle irrigation. The average yield difference between the irrigation methods was statistically significant (t-test, $\alpha=0.05$ ). The small plot experiment showed tomato yield to decrease as applied water decreased. Tomato yield was unaffected by the range of soil salinity in these fields, which in one field, exceeded the threshold soil salinity of tomatoes of 2.5 $\mathrm{dS} \mathrm{m}{ }^{-1}$. (The threshold soil salinity, expressed as the electrical conductivity of the saturated extract, is the maximum root zone soil salinity at which no yield reductions occur.) The average difference in soluble solids between the two irrigation methods was not statistically significant. However, the small plot experiment showed soluble solids to increase as applied water decreased. Based on a crop price of $\$ 55 \mathrm{Mg}^{-1}$, drip irrigation increased profits by $\$ 1284 \mathrm{Mg}^{-1}$ compared to sprinkle irrigation.

At the fourth site, the small-scale randomized replicated experiment showed tomato yield to range from $77.5 \mathrm{Mg} \mathrm{ha}^{-1}$ for $396 \mathrm{~mm}$ of applied water to $95.9 \mathrm{Mg}$ $\mathrm{ha}^{-1}$ for $589 \mathrm{~mm}$ of water. The regression between yield and applied water was highly significant at a level of significance of $0.05(\mathrm{P}=0.0008)$. Soil salinity at this field exceeded the threshold soil salinity.

Soil salinity around drip lines was found to depend on the depth to the ground water, salinity of the shallow ground water, salinity of the irrigation water, and amount of applied water. For water table depths of $2 \mathrm{~m}$, soil salinity (expressed as the EC of a saturated extract) was smaller than the threshold salinity and was distributed relatively uniformly around the drip line (Fig. 1A). For water table depths of less than $1 \mathrm{~m}$, soil salinity varied considerably around drip lines with the smallest levels near the drip line and high values near the periphery of the wetted volume (Fig. 1B). Higher values of soil salinity occurred near the drip line for the field using the higher EC irrigation water (Fig. 1C).

The key to the profitability and sustainability of drip irrigation of tomatoes in the valley's salt affected soils is salinity control. Salinity control requires leaching or flushing of salts from the root zone by applying irrigation water in excess of the soil moisture depletion. The leaching fraction, defined as the percent of applied water that percolates below the root zone, is used to quantify the amount of leaching. For sprinkle and furrow irrigation, the field-wide leaching fraction historically has been calculated as the difference between the seasonal amount of applied water and the seasonal crop evapotranspiration.

It was concluded that because of salinization issues, sustainable agriculture may not be possible in these salt affected soils of the valley, based on a regional salt balance assessment which showed salt imports into the valley to exceed salt exports [5]. Data from these experiments showed that based on the historical 
approach to calculating leaching fractions, little or no field-wide leaching occurred, which appears to support this conclusion. Yet, considerable localized leaching occurred around the drip lines, as seen in Fig. 1. The higher the amount of applied water, the higher the localized leaching around the drip line, as evidenced by the larger zone of low salt soil for $589 \mathrm{~mm}$ of applied water compared to $397 \mathrm{~mm}$ of water (Fig. 2). This localized leaching appears to be the main contributor to the high yields previously mentioned. Thus, the historical approach to estimating leaching fractions may be inappropriate for drip irrigation. However, it is difficult to estimate the localized leaching fraction under drip irrigation because leaching fraction, soil salinity, soil moisture content, and root density all vary with distance and depth around drip lines.

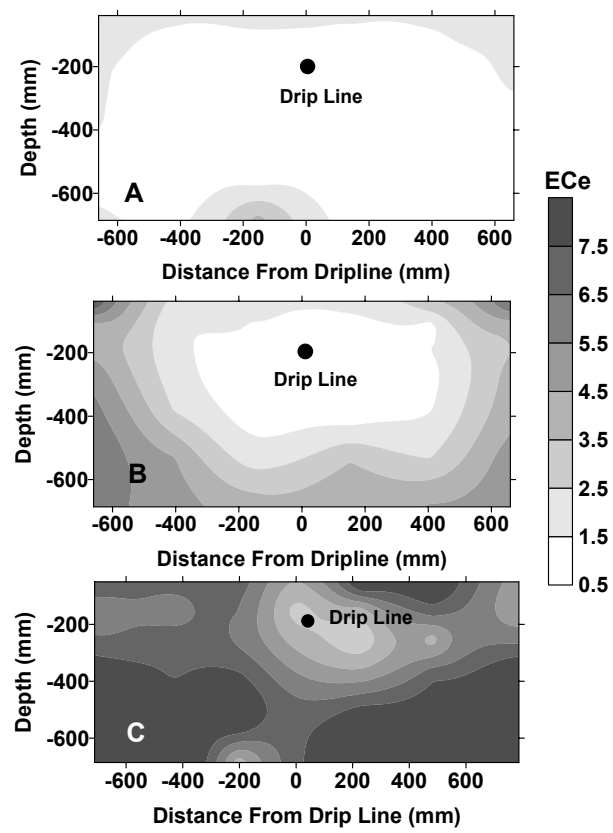

Figure 1: $\quad$ Patterns of soil salinity around drip lines for (A) an average water table depth of $2 \mathrm{~m}$ and an $\mathrm{EC}$ of the irrigation water equal to $0.3 \mathrm{dS}$ $\mathrm{m}^{-1}$; (B) a water table depth between 0.61 and $1 \mathrm{~m}$ and an EC of the irrigation water equal to $0.3 \mathrm{dS} \mathrm{m}^{-1}$, and (C) a water table depth between 0.61 and $1 \mathrm{~m}$ and an EC of the irrigation water equal to 1.1 $\mathrm{dS} \mathrm{m} \mathrm{m}^{-1}$.

\section{Conclusions}

From a macroscopic viewpoint based on a field-wide or regional basis, a sustainable agriculture may not be possible in the valley's saline soils because of an apparent lack of leaching. However, from a microscopic viewpoint (root zone 
around drip lines), substantial localized leaching occurred, even under severe saline conditions, and thus, a sustainable agriculture may be possible with drip irrigation. Based on these experiments, the following are recommended for successful drip irrigation of processing tomatoes under saline shallow ground water conditions:

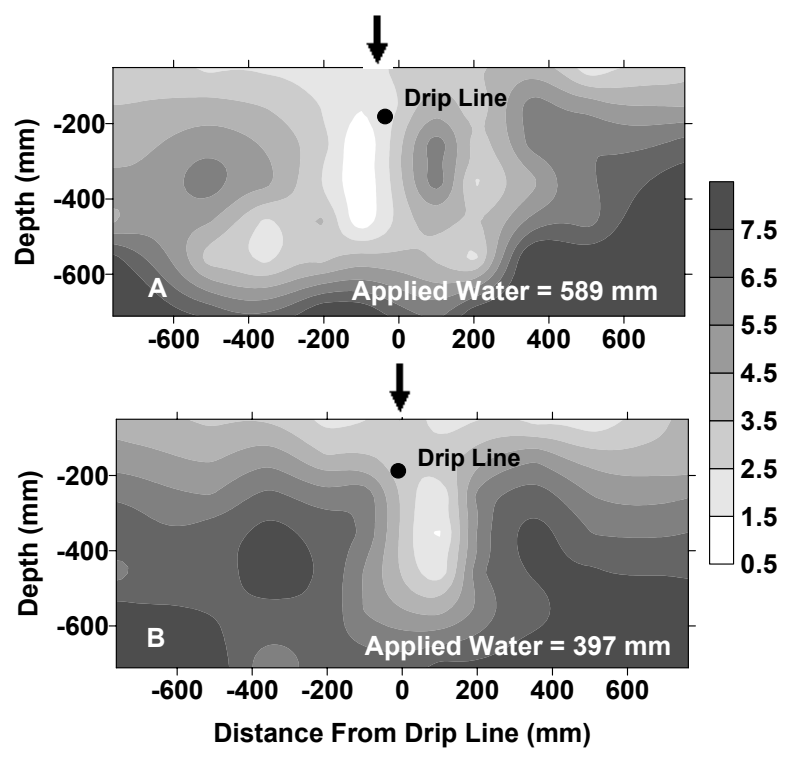

Figure 2: $\quad$ Effect of amount of applied irrigation water on the patterns of soil salinity around the drip line.

- Sufficient leaching must occur near drip lines to maintain profitable yields.

- Salinity of the irrigation water should be less than $1.1 \mathrm{dS} \mathrm{m}^{-1}$.

- Seasonal water applications should be about equal to the seasonal crop water use. This water application appears to provide sufficient localized leaching. Higher applications could raise the water table; smaller applications could decrease tomato yield due to reduced leaching and possibly, decreased soil moisture content.

- Drip irrigation systems must be designed for high field-wide uniformity of applied water.

- Periodic leaching of salt accumulated above the buried drip lines will be necessary with sprinklers for stand establishment if winter and spring rainfall is insufficient to leach the salts. 
- Periodic system maintenance must be performed to prevent clogging of drip lines. Clogging will not only reduce the applied water needed for crop ET, but also reduce the leaching.

\section{References}

[1] Hanson, B.R. \& Ayars, J.E., Strategies for reducing subsurface drainage in irrigated agriculture through improved irrigation. Irrigation and Drainage Systems 16, pp 261-277, 2002.

[2] Fulton, A.E., Oster J.D., Hanson, B.R., Phene, C.J., \& Goldhamer, D.A., Reducing drain water: furrow vs. subsurface drip irrigation. California Agriculture 45(2), pp.4-8, 1991.

[3] Styles, S., Oster, J.D., Bernaxconi, P., Fulton, A. \& Phene, C., Demonstration of emerging technologies. Agroecosystems: Sources, Control and Remediation, ed. J. Guitjens \& L. Dudley, Pacific Division, Am. Assoc. Adv. Sci., San Francisco, pp. 183-206, 1997.

[4] Hanson, B.R. \& May, D.M, Effect of subsurface drip irrigation on processing tomato yield, water table depth, soil salinity, and profitability. Agricultural Water Management 68, pp. 1-17, 2004.

[5] Schoups, B., Hopmans, J.W., Young, C.A., Vrugt, J.A., Wallender, W.W., Tanji, K.K., \& Panday, S. Sustainability of irrigated agriculture in the San Joaquin Valley, California. Proceedings of the National Academy of Sciences of the United States of America 102(43), pp. 15352-15356, 2005. 